\title{
Managerial Styles and Employee Performance. An Empirical Study from Bank Sector Employees in Greece
}

\author{
STAVROS KALOGIANNIDIS \\ University of Western Macedonia \\ Department of Business Administration \\ GREECE \\ ORCiD: https://orcid.org/0000-0002-2337-5775 \\ STAMATIS KONTSAS \\ Department of Business Administration \\ University of Western Macedonia \\ GREECE \\ FOTIOS CHATZITHEODORIDIS \\ University of Western Macedonia \\ Department of Regional and Cross Border Development \\ Kozani, GREECE
}

\begin{abstract}
The aim of the paper was to assess the level to which managerial styles in an organization affect employee performance among selected banks in Greece. The study focused on three major managerial styles which include; democratic, autocratic and participatory styles of management. The study utilized a descriptive research design and an online survey was used to collect relevant data from different employees attached to selected banks in Greece (National Bank of Greece, Piraeus Bank, Citibank Greece, and HSBC Greece). The survey targeted 220 employees though only a response rate of $87.3 \%$ was obtained based on 200 employees that answered questions contained in the survey questionnaire. The different study findings showed that all the managerial styles are positively associated with employee performance except autocratic managerial style which had a positive but insignificant relationship with employee performance. The study concluded that it is very important for managers to continuously apply different innovative managerial styles in executing their duties since this has a great impact on the general performance of employees.
\end{abstract}

Key-words:- Managerial styles, autocratic, democratic, participatory, employee, performance.

Received: May 25, 2021. Revised: October 29, 2021. Accepted: November 26, 2021. Published: December 17, 2021.

\section{Introduction}

\subsection{Background to the Study}

The general evolution of the practice of management and the impact it renders on employee performance and productivity has received greet attention in the recent majorly due to the importance of employee performance or productivity on the overall growth of an organization [1]. Organizations across the world largely depend on the efforts or input showcased by their employees at the different levels of management. The field of management has evolved since the $17^{\text {th }}$ century and continues to evolve due to the increasing technological advancements in the modern world, that have changed the way employees execute their operation or activities at the workplace. With increase in globalization and modernity as a whole, employees are increasingly being treated with humanity which relatively different from the treatment rendered to them in the past centuries where they were treated like machines. Most modern organizations have continuously focused on adopting more employee centered managerial styles in order to compete favorably on the global market[1], [2]. 
Most studies indicate that in order to achieve enhanced growth in any business, organizations must apply the most appropriate managerial styles that are solely focused on improving the welfare of the employee and consequently maintaining high productivity in the organization[3]-[5]. According to [6], the most effective managerial styles include; participatory management style, democratic management styles, and Autocratic management styles. Every style of management improving the performance is very important in improving the general performance of employees and consequently maintaining steady organizational growth[7].

Most management scholars argue that the performance of any organization is greatly dependent on the style of management applied during the different activities or operations of the organization [4], [8]. Some scholars assert that participatory managerial style is the most effective in increasing the productivity of employees and consequently maintaining steady organizational growth [9]. Participatory managerial style encourages employees to actively participate different organizational activities with great morale and commitment. Employee performance which entirely depends on management styles is considered a very important asset of an organization and must be annualized by organizations hence it is appropriate to conduct a study to determine the relationship that exists between different styles of management and performance of an employee.

\subsection{Problem Statement}

Different studies reveal that organizational performance entirely depends on the input rendered by the workforce. Committed and highly motivated employees help to improve the growth of any organization. The commitment and general productivity of employees is enhanced by different situational factors at the workplace. Managers or leaders are so influential concerning the behavior and level of commitment exhibited by employees when executing different operations or activities of an organization[4]. According to studies, labor in most Greek firms is task-focused and monotonous, with little freedom, and yet choices and regulations are forced on subordinates[8], [10]. Workers would pretend to perform well in companies such as financial institutions where management views employees as mere hands to get the job done because of the standards and measures set to them[9]. Managers must motivate personnel, including those who report to them, coworkers, superiors, and customers, to do their tasks. As a result, the human aspect must be scrutinized alongside staff performance for successful and efficient organization administration. The study therefore sought to establish the impact of management styles employee performance in organizations most especially the banking institutions in Greece.

\subsection{Objective of the Study}

The main aim of the study is to investigate the effect of management styles on employee performance. Specifically, the study seeks:

- To establish the relationship participatory management style and employee performance.

- To establish the relationship between autocratic managerial style and employee performance

To determine the relationship between democratic managerial style and employee performance.

\subsection{Hypothesis of the Study}

H1: There is no relationship between participatory managerial style and employee performance

$\mathrm{H} 2$ : There is a relationship between autocratic managerial style and employee performance.

H3: There is no relationship between democratic managerial style and employee performance

\subsection{Scope of the Study}

The research used employee performance as the dependent variable and management styles as the independent variable (participatory, autocratic, and democratic management styles). The dependent variable seeks to demonstrate the overall influence brought in by the effect of the independent factors, while the independent variables drive a stated change in the reason of variations in the dependent variable.

\subsection{Significance of the Study}

This research looked at how various management styles affect employee performance in order to get a better picture of how employees in a company perform overall. The outcome will demonstrate and identify the various effects management styles have 
on overall employee performance as opposed to managerial, interpersonal, or interactive knowledge for management arrangements, as well as ways to improve organizational productivity by adjusting or adopting different management styles.

The outcomes of the research are likely to aid corporations or organizations who want to get better results from their employees by using innovative management techniques.

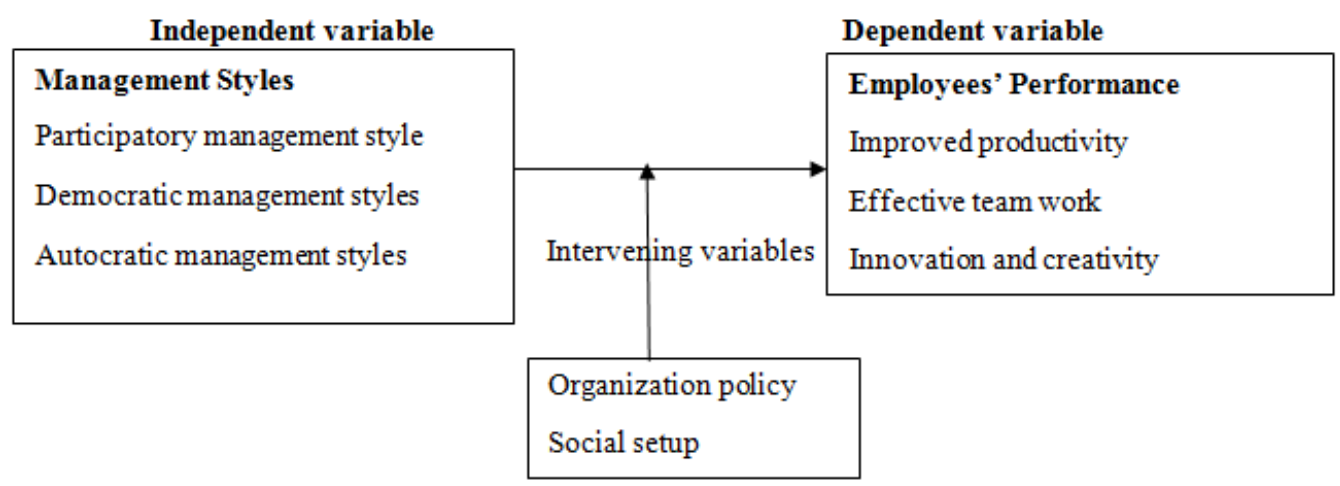

Source: adapted from Saleem et al. [5]

Fig. 1: Conceptual Framework

encourages the application of the most appropriate strategies that can motivate employees at the

\section{Literature Review}

\subsection{Theoretical Review}

The contingency theory by Fiedler was based on to explain the relationship that exists between the different styles of management and employee performance [11]. The theory asserts that the general ability of any leader to manage an organization is greatly based on different situational factors that cut across the leaders' most desired managerial style, and the abilities and attributes of workers or employees that depend heavily on the different situational factors. The contingency theory proposes a unique approach or strategy to employee management that focuses on addressing the situation first instead the other organizational needs. In this case, the theory encourages application of a particular managerial style that will help to stimulate individual employee performance at a particular time in an organization [11].

The contingency theory is associated different assumptions that most leaders base on in improving the productivity and general commitment employees in organizations. The first assumption of the theory states that "an individual who focus on influencing the abilities of others, must apply both supportive and directive behaviors"[12]. This assumption
Future academic academics and researchers will benefit from the study since it will contribute to the body of knowledge on the issue of the impact of management styles on employee performance.

\subsection{Conceptual Framework}

workplace thereby improving their productivity and consequently improve the performance of the organization. However this assumption failed to address the issue of inherent change in different human behaviors on which most management practices are based hence it left a big gap in the field management necessitating scholars to undertake different empirical studies to establish the impact of this assumption on the behavioral attributes of employees when executing different activities of an organization. The theory also assumes that every managerial style is greatly dependent on the prevailing situation in a particular organization [13]. This assumption is based on the fact that the different behavioral patterns leaders help them to develop different abilities or competences necessary in enhancing the effectiveness of different managerial styles most especially in improving employee. However this theory also left gasp in the area of management majorly due to the fact that most scenarios were greatly determined by both external and internal factors that affected the nature in which employees addressed different situations in an organization [12]. 


\subsection{Empirical Review}

\subsubsection{Management Styles}

\subsubsection{Participatory Management Style}

The concept of participatory management is greatly depend on the behavioral school of thought that asserts that employee's productivity is greatly influenced by their level of participation on a particular task or job. In this case increased active participation of employees on different activities of an organization greatly enhances their commitment and productivity thereby improving their general performance. Cai et al. [14] indicate that participatory management skills and principles were majorly impacted by the different aspects of organizational behavior. Studies indicate that participatory management is concerned with managers or leaders sharing their abilities, knowledge, power and influence through continuously encouraging their employees to improve their performance[15], [16]. Whereas some scholars disagree with the effectiveness of the participatory style of management in enhancing employee performance, most recent studies indicate that participatory management is a viable management style that can help modern organization to improve their competitive advantage and consequently compete favorably on the global market. In a study conducted by Saleem et al. [5] about the levels of performance of over 500 or more employees, it was revealed that the different efforts under participatory style of management had helped employees to improve their productivity in executing different duties at the workplace.

\subsubsection{Democratic Management Style}

Democratic management style is based on leaders or managers showcasing their knowledge, power, kills and abilities to an entire employee group as a whole. In this case, managers handle employees and consequently apply different policies and regulations without discrimination or favoritism such that all employees are impacted equally[17]. Research also indicates that concerning democratic managerial style, the leaders tend to encourage continued interactions among the employee groups and consequently focus on enhancing the relationship between the top management and other lower levels of management as well as the entire employee team[3]. Studies indicate that consistent proper interaction within an organization greatly enhances the productivity of employees which in the longrun helps to improve the general performance of an organization [9].

Sasidaran [7] indicates that under democratic style of management, leaders are entirely team players and continuously share different management function with employees which acts as a source of motivation to employees. The core role of a manager under democratic management style is to act as a conference leader instead of a decision taker. In this case, the manger allows the different decisions in the organization to emerge from the various discussions among employee groups instead of imposing the decisions of employees without their involvement [5]. This management style is most effective in situations where the employees are willing to share their thoughts and concerns with the employer such that a common solution or agreement can be reached between the two groups. The focal point of this management style is that the willingness of the employer to share different decision making concerns with the employees before implementing them in the organization. The democratic management style is acknowledged as a very important of employee empowerment and improved collaboration in an organization [7].

\subsubsection{Autocratic Management Style}

Various studies have revealed that the autocratic style of management also plays some role in improving the input levels of employees when presented with different tasks [16], [18]. Al Khajeh [17]indicates that under autocratic style of management, the utmost authority always remains with the manager and he undertakes different decisions with an assumption that the employees or subordinates will accept the decisions. In this case, the manger doers not mind much about the attitudes and opinions of employees hence undertakes decisions independently and applies them without any consultations concerning their level of impact on the employee groups and organization as a whole. Alhassan et al.[18] indicate that under autocratic management style, the manager is much concerned with the task being completed and not the reaction of employees when doing the different assigned tasks.

Most studies have revealed that the main role of a manager under this style of management is to guide employees on how a particular task ought to be done[14]. In this case, the manager serves as a good example to the different subordinates though no consultation are made when undertaking the decisions concerned with a particular task. The aspects of autocratic style of management are relatively similar to management styles namely; Likert's I and II styles. Studies indicate that under the autocratic style of management, the main authority is entirely with the manager hence all key communications and feedback within the employee 
group are directed towards the manager [6]. Some scholars argue that autocratic management style may not enhance productivity of employees when applied monotonously since employees' feelings, opinions or attitudes are not much appreciated. However, according to certain research, this approach may be quite successful in emergent circumstances and is typically justified by the group, that is, when the group's overall environment is supportive and mature.[10].

\subsubsection{Employee Performance}

Performance is interpreted as standards for employee behavior at work. Employees are assed and rated on the level of commitment or productivity on a particular job as compared to the needs and goals of the employer or the organization [19]. Performance has several components, all of which must be properly defined in order to be fair to both the individual and the firm.

\subsubsection{Improved Productivity}

Most scholars have in the past ignored the concept of productivity in measuring the general influence of different management practices on the performance of employees in banking institutions [5]. Most of the banking institutions are currently experiencing increased demand for new innovations from the modern class of customers whose tastes and desires have greatly changed due to changes in technology. Consequently employees' ability to address such customer requires proper supervision and management from the leaders of the organization. Studies indicate that productivity of employees in the current modern world is greatly depend on the level, nature and style of management employed by the top management[7]. This in the longrun has a great impact on how employees respond to the different assignments or tasks presented to them[17]. According to Bhatti et al. [16] the level of productivity in an organization presents the extent to which an employer extracts the employee output from a particular level of input. Inputs are associated with employees' skills, knowledge, innovations, creativity and level of commitment in relation to a particular task in an organization. Studies indicate that in order to achieve improved employee performance, companies are increasingly undertaking efforts towards improving quality and productivity and consequently reduce operational costs [6], [7].

\subsubsection{Effective Teamwork}

Employees' performance in a particular organization is also measured based on the level of teamwork showcased when undertaking different task assigned to a particular employee group. Studies indicate that the efficiency of employees is normally improved through working together and sharing ideas about different activities in an organization [6], [8].

According to Chung \& Climate (2020), the major element of improving team work among employees is by focusing on the common goal and continuously having a clear purpose for the different efforts employed by the entire employee group. Teams play a key role in the growth of organizations mangers are encouraged to focus on establishing strategic and goal-oriented teams among their subordinates. In order to establish and foster a healthy, effective team environment, successful collaboration depends on synergism amongst all team members creating an atmosphere where they are all motivated to contribute and engage. Research indicates that successful teamwork are those established based on the beliefs of the involved team members[18]. In this case, success of the team is much dependent on team members creating an environment that involves increased willingness of members to actively participate towards promoting and establishing a positive, effective team environment. Studies indicates that flexibility is an important element for any employee team and this involves team members being able to effectively adapt to the different work environments where organizational goals are attained majorly through different practices of collaboration and social interdependence rather than individualized, and highly competitive goals [19].

\subsubsection{Job Satisfaction}

According to Bourini et al. [20], the level of job satisfaction among employees greatly influences their commitment and productivity on a particular job. This justifies the reason to why most scholars suggest that managers ought to focus on enhancing the job satisfaction levels of employees in a particular organization. Many theories have been developed explaining the way different managers of interest to managers enhance the levels of job satisfaction in their individual organizations. Research indicates that satisfaction can be improved by managers or employers meeting the different needs of employees and consequently motivating or encouraging them to become more committed on their jobs[17], [20]. 
Maslow classified human wants into five categories: physiological, safety and security, belonging, esteem, and self-actualization. [21].

According to Maslow's pyramid, the different needs at the lower levels of management should always be met or fulfilled before leaders can focus on the needs at the higher levels of the organization. The Maslow's theory asserts that the concept of job satisfaction can be best explained based the perspective of need fulfillment [21], [22]. In this case, employees must be encouraged and motivated to obtain the best out of their jobs. The theory shows that employees' satisfaction is much dependent on how their needs are met. Herzberg and his colleagues developed Herzberg's motivationhygiene theory of work satisfaction, which states that there are two sorts of needs: intrinsic and extrinsic. This theory explains that job satisfaction is to a great extent a function of two need systems hence employees' job satisfaction is enhanced by meeting the dynamics of the two need systems [22].

\subsection{Conclusion}

The literature reviewed in this study revealed a growing number of management styles, including participative management, democratic management, and autocratic management. Each of these is linked to different aspects of effective management in an organization, but research shows that there has been a shift in emphasis away from employee characteristics and behaviors and how they are influenced by the various management styles used by managers, as well as the resulting level of performance of employees as a result of these styles[18]. As a result, there is a significant gap between management and employee performance. As a result, the goal of this research is to bridge the gap between the influence of participative, democratic, and authoritarian management styles on overall employee performance, particularly in Greek financial organizations.

\section{Methodology}

A descriptive survey research approach was used in this study. Employees of a restricted group of Greek banks were the target audience. National Bank of Greece, Piraeus Bank, Citibank Greece, and HSBC Greece were among the banks involved. A total of 200 questionnaires were recovered, resulting in a response rate of 87.3 percent. The information was gathered utilizing a well-designed survey questionnaire that was put online and allowed diverse workers to express their thoughts on the influence of managing styles on employee performance. The rationale for picking these respondents was that bank workers have the finest expertise on which to make a determination of the extent to which management styles impact overall employee performance in any firm. Employees of the chosen banks were invited to participate in the research if they agreed and were willing to answer various questions on the subject.

Additional information on management styles and employee performance was gathered from a variety of secondary sources, including journals, textbooks, and government papers. The study instrument included questions on the dependent and independent variables as well as personal information about the respondent. The questions were graded on a 5-point Likert scale, with 5 indicating strong disagreement and 1 indicating agreement. The Pearson's rank correlation coefficient was utilized to determine the association between the research variables, which was done using SPSS. Tables were used to show the findings, which were then evaluated using frequencies and percentages. This technique of presenting and evaluating data was used for this survey because it allows for a more full explanation of respondents' narratives and perspectives, allowing for a more decisive answer to the study's primary research question.

\section{Results}

This section presents an interpretation of the different results based on the data obtained from the survey with the employees of different selected banks in Greece.

\subsection{Demographic Characteristics}

The study involved participation of both and female bank employees whereby majority of the respondents $(71.5 \%)$ were male and only $28.5 \%$ were female as shown in figure 2 .

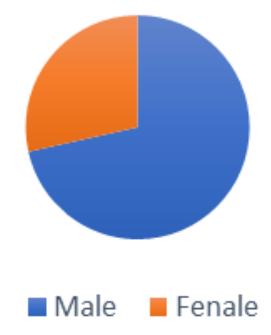

Fig. 2: Gender distribution of participants Source: Survey (2020) 
Concerning the years of experience in the banking institutions, majority of the respondents $(66.5 \%)$ 0-5 years of experience, $13 \%$ had 6-10 years of experience while the least number of respondents has 23 years and above as shown in figure 3.

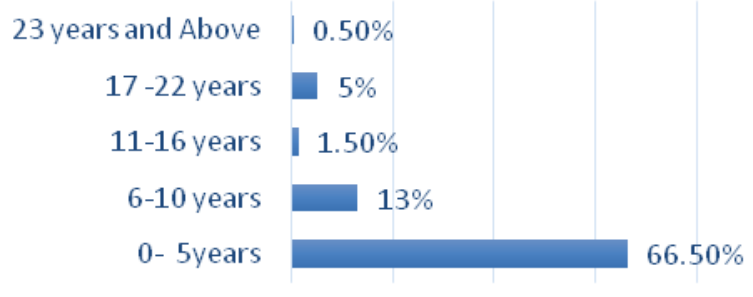

$0.00 \% 20.00 \% 40.00 \% 60.00 \% 80.00 \%$

Fig. 3: Years of experience in the banking sector Source: Survey (2020)

Concerning bank affiliation, majority of the participants $(34.5 \%)$ were affiliated to Citibank, $22 \%$ were affiliated HSBC Greece and Piraeus Bank respectively while the least number of respondents $(21.5 \%)$ were affiliated to National Bank of Greece.

\begin{tabular}{|c|c|c|c|c|}
\hline $40.00 \%$ & \multicolumn{4}{|c|}{$34.50 \%$} \\
\hline $30.00 \%$ & $21.50 \%$ & $22 \%$ & & $22 \%$ \\
\hline $20.00 \%$ & & & & \\
\hline \multicolumn{5}{|l|}{$10.00 \%$} \\
\hline & $\begin{array}{l}\text { National } \\
\text { Bank of } \\
\text { Greece }\end{array}$ & $\begin{array}{c}\text { Piraeus } \\
\text { Bank }\end{array}$ & $\begin{array}{c}\text { Citibank } \\
\text { Greece }\end{array}$ & $\begin{array}{l}\text { HSBC } \\
\text { Greece }\end{array}$ \\
\hline
\end{tabular}

Fig. 4: Bank affiliation for the participants Source: Survey (2020)

\subsection{Analyses of Democratic Management Style}

Most of the study participants (48\%) were in strong agreement with the fact that democratic management style has a big influence on employees' performance in an organization, while the least number of study respondents (7\%) were not sure on whether democratic management style impacts employee performance as presented in table 1.

Table 1. Opinions on democratic management style and employee performances

\begin{tabular}{|l|c|c|}
\hline \multicolumn{1}{|c|}{ Statement } & $\begin{array}{c}\text { Frequency } \\
(\mathbf{n = 2 0 0 )}\end{array}$ & $\begin{array}{c}\text { Percentage } \\
(\mathbf{\%})\end{array}$ \\
\hline Strongly agree & 96 & 48 \\
\hline Agree & 76 & 38 \\
\hline
\end{tabular}

\begin{tabular}{|l|c|c|}
\hline Not sure & 7 & 3.5 \\
\hline Disagree & 12 & 6 \\
\hline Strongly Disagree & 9 & 4.5 \\
\hline Total & $\mathbf{2 0 0}$ & $\mathbf{1 0 0}$ \\
\hline
\end{tabular}

Source: Survey (2020).

\subsection{Analyses of Autocratic management Style} Majority of the study participants $(43 \%)$ were in strong agreement with the fact that autocratic management style influences employees' performance, while the lowest number of study participants $(11 \%)$ were not sure whether autocratic management style impacts employee performance. However, a significant number participants (21.5\%) disagreed with the assertion that this management style impacts employees performances. This could be based on the fact that mangers using this management style do not consider the opinions and attitudes of employees during the decision making processes.

Table 2. Opinions on autocratic management style

\begin{tabular}{|l|c|c|}
\hline \multicolumn{1}{|c|}{ Statement } & $\begin{array}{c}\text { Frequency } \\
(\mathbf{n = 2 0 0 )}\end{array}$ & $\begin{array}{c}\text { Percentage } \\
(\mathbf{\%})\end{array}$ \\
\hline Strongly agree & 86 & 43 \\
\hline Agree & 31 & 15.5 \\
\hline Not sure & 11 & 5.5 \\
\hline Disagree & 43 & 21.5 \\
\hline Strongly Disagree & 29 & 14.5 \\
\hline Total & $\mathbf{2 0 0}$ & $\mathbf{1 0 0}$ \\
\hline
\end{tabular}

Source: Researcher's Compilation (2020).

\subsection{Analyses of Participatory Management Style}

Concerning the impact of participatory management on the performance of employees, majority of the participants (91\%) strongly agreed that this style greatly impact on employees' performance, while no participant disagreed with this assertion.

Table 3. Opinions on participatory management style

\begin{tabular}{|l|c|c|}
\hline \multicolumn{1}{|c|}{ Statement } & $\begin{array}{c}\text { Frequency } \\
(\mathbf{n = 2 0 0})\end{array}$ & $\begin{array}{c}\text { Percentage } \\
(\mathbf{\%})\end{array}$ \\
\hline Strongly agree & 182 & 91 \\
\hline Agree & 13 & 6.5 \\
\hline Not sure & 5 & 2.5 \\
\hline Disagree & 0 & 0 \\
\hline Strongly Disagree & 0 & 0 \\
\hline Total & $\mathbf{2 0 0}$ & $\mathbf{1 0 0}$ \\
\hline
\end{tabular}


Source: Survey (2020)

\subsection{Relationship between Management Styles and Employee Performance}

The study was aimed at establishing the relationship between Participatory management style and Employees' performance. In order to establish this relationship, a cross tabulation of the responses on the aspects of participatory management style' and the effect of managerial styles on employees' performance was conducted and the correlational analysis was then conducted to establish the level of the relationship between the two variables. The results obtained and the subsequent Pearson's coefficient values are presented in table 4 .

Table 4. Correlation between participatory management style and Employee performance

\begin{tabular}{|c|c|c|c|}
\hline & & $\begin{array}{l}\text { Participatory } \\
\text { management } \\
\text { style }\end{array}$ & $\begin{array}{l}\text { Employee } \\
\text { performance }\end{array}$ \\
\hline \multirow{3}{*}{$\begin{array}{l}\text { Participatory } \\
\text { management } \\
\text { style }\end{array}$} & \multirow{3}{*}{$\begin{array}{l}\text { Pearson } \\
\text { Correlation } \\
\text { Sig. (2-tailed) } \\
\mathrm{N}\end{array}$} & 1 & $.117^{* *}$ \\
\hline & & & .000 \\
\hline & & 200 & 200 \\
\hline \multirow[t]{3}{*}{$\begin{array}{l}\text { Employee } \\
\text { performance }\end{array}$} & \multirow{3}{*}{$\begin{array}{l}\text { Pearson } \\
\text { Correlation } \\
\text { Sig. (2-tailed) } \\
\mathrm{N}\end{array}$} & $.117^{* *}$ & 1 \\
\hline & & .000 & \\
\hline & & 200 & 200 \\
\hline
\end{tabular}

**. Correlation is significant at the 0.01 level (2tailed).

After cross tabulation and analysis, it was shown that participative management style and employee performance had a significant association ( $\mathrm{r}=$ $\left.0.117^{* *}, \mathrm{n}=200, \mathrm{p}=.000\right)$. The findings clearly reveal that several components of participative management style, such as increasing employee engagement, have a significant influence on employee performance, leading to the null hypothesis being accepted. $\mathrm{H}_{1}$ that there is a significant relationship between participatory management style and employees' performance.

The study also explored the relationship that exists between autocratic management style and the general performance of employees. Pearson's rank correlation analysis was conducted and used to establish the relationship so as to confirm the overall impact of autocratic management style and employees' performance. The results obtained and the subsequent Pearson's coefficient values are presented in table 5 .
Table 5. Correlation between autocratic management style and employees performance

\begin{tabular}{|l|l|c|c|}
\hline & & $\begin{array}{l}\text { Autocratic } \\
\text { management } \\
\text { style }\end{array}$ & $\begin{array}{l}\text { Employee } \\
\text { performance }\end{array}$ \\
\hline $\begin{array}{l}\text { Autocratic } \\
\text { management } \\
\text { style }\end{array}$ & \begin{tabular}{l} 
Pearson \\
Correlation \\
\cline { 3 - 4 }
\end{tabular} & 1 & $.214^{* *}$ \\
\cline { 3 - 4 } & Sig. (2-tailed) & & .025 \\
\cline { 3 - 4 } $\begin{array}{l}\text { Employee } \\
\text { performance }\end{array}$ & $\begin{array}{l}\text { Pearson } \\
\text { Correlation }\end{array}$ & 200 & 200 \\
\cline { 3 - 4 } & Sig. (2-tailed) & .025 & 1 \\
\cline { 3 - 4 } & $\mathrm{N}$ & 200 & 200 \\
\hline
\end{tabular}

**. Correlation is significant at the 0.01 level (2tailed).

Source: Primary Data (2020)

There is a strong association between autocratic management style and employee performance $(\mathrm{r}=$ $0.214 * *, \mathrm{n}=200, \mathrm{p}=.025)$, according to cross tabulation and correlational analysis. The findings clearly reveal that the many aspects of autocratic management style have a significant impact on employee performance in firms. The null hypothesis $\mathrm{H} 2$, that there is a strong association between autocratic management style and employee performance, was also accepted as a consequence of these findings.

Table 6 shows the Pearson's rank correlation coefficient values that were used to demonstrate a link between democratic management style and employee performance.

Table 6. Correlation between democratic management style and employees performance

\begin{tabular}{|c|c|c|c|}
\hline & & $\begin{array}{l}\text { Democratic } \\
\text { management } \\
\text { style }\end{array}$ & $\begin{array}{l}\text { Employee } \\
\text { performance }\end{array}$ \\
\hline \multirow{3}{*}{$\begin{array}{l}\text { Democratic } \\
\text { management } \\
\text { style }\end{array}$} & \multirow{3}{*}{$\begin{array}{l}\text { Pearson } \\
\text { Correlation } \\
\text { Sig. (2-tailed) } \\
\mathrm{N}\end{array}$} & 1 & $.327^{* *}$ \\
\hline & & & .013 \\
\hline & & 200 & 200 \\
\hline \multirow[t]{3}{*}{$\begin{array}{l}\text { Employee } \\
\text { performance }\end{array}$} & \multirow{3}{*}{$\begin{array}{l}\text { Pearson } \\
\text { Correlation } \\
\text { Sig. (2-tailed) } \\
\text { N }\end{array}$} & $.427^{* *}$ & 1 \\
\hline & & .013 & \\
\hline & & 200 & 200 \\
\hline
\end{tabular}


**. Correlation is significant at the 0.01 level (2tailed).

Source: Survey (2020)

There is a strong association between autocratic management style and employee performance $\left(\mathrm{r}=0.427^{* *}, \mathrm{n}=200, \mathrm{p}=.013\right)$, according to cross tabulation and correlational analysis. In this scenario, the many characteristics of democratic management style have a significant impact on employee performance, thus managers should constantly prioritize sharing their knowledge, attitudes, abilities, and perspectives with their subordinates. The null hypothesis was likewise accepted as a consequence of these findings. $\mathrm{H}_{3}$ that there is a significant relationship between democratic management style and employee performance.

\section{Discussion}

The study findings confirm the relevance of managerial styles towards enhanced performance of employees. The influence of different styles of management on the commitment and productivity of employees is evident across all the hypothesis that were tested under this study. The literature review also confirmed the relevance of employers applying innovative and effective management styles in managing their subordinates as it greatly influences employee performance and consequently on organizational growth. Proper management of employees in sectors such as agriculture helps to build the social capital of employees, their motivation and enhances their performance at the workplace[1], [23]. The study revealed that democratic style of management gives employers an opportunity to share their knowledge and skills equally and appropriately with their employees and this motivates the different employee groups in the organization. This is in line with the works of [9], [17], [20]; who explained the relevance of a democratic style of management as a veritable tool that help to improve the general performance and commitment of employees at the workplace. This is also evidenced by the high regression that exists between the leadership style and the dependent variable of this study. Second, the study's results revealed that transactional leadership style is crucial for employees to operate in the organization's best interests. This is consistent with the findings of Alhassan et al.,[18] who stated that participatory management recognizes the leader's or manager's specific expectations, provides rewards in exchange for the leader's or manager's performance, and is unambiguously planned to express and recompense in-role performance. The results obtained also confirm that management styles are very essential in enhancing the performance levels of organizations. According to Seery[22], the management style of any business is seen as a critical part of employee empowerment, teamwork, and cooperation. It has been found that when individuals who will be impacted by the organization's actions are fully engaged in the decision-making process, the organization becomes more successful. When subordinates are permitted to actively engage in decision-making, it is considered that they share a feeling of responsibility for the company [5], [24]. Groups from banking sector that reached the highest overall efficiency values over time are mostly those of medium size[25].

\section{Conclusion}

The study confirms the influence of proper managerial styles on the general productivity of employees in an organization. The results of the research show that transformational and democratic management styles are the best for managing employees in institutions such as banks; hence contribute greatly to improved employee productivity. Practices of transformational management of employees such seeking employee feedback, proper or effective communication with employees and agitating for employee rewards, help to enhance employee productivity.

The results of the research show that transformational and democratic management styles are the best for bank management in Greece to adopt in order to become more competitive in the global financial market. In this instance, businesses should use a democratic management style and humane management techniques to ensure that the staff is appropriately committed to the job tasks.

Apart from an organization's management styles, there are other aspects to examine that might influence employee performance in Greece financial institutions favorably or adversely, such as organizational conflict, organizational politics, organizational atmosphere, and motivation. Future research should concentrate on the aforementioned characteristics and objectively prove their link to employee performance.

The managerial styles are important elements of every organization hence managers have to continuously focus on applying the most appropriate styles that are employee centered such as participatory and democratic management styles. This helps to improve employees' performance and 
consequently improve the performance of the whole organization.

References:

[1] Papavasili, T., Kontogeorgos, A., Siskou, T., Chatzitheodoridis, F. 2019. Municipal Employees in the Era of Economic Crisis: Exploring Their Job Satisfaction. Public Administration Issues, (5) 2019: pp. 120-139 (doi:10.17323/1999-5431-2019-0-5-120-139).

[2] A. Kontogeorgos, Chatzitheodoridis, F. (2019)"Workers or Investors? Investigating the Reciprocity Aspects among Greek Social Enterprises Members i Trabajadores o Inversores? Investigar los aspectos de reciprocidad entre los miembros de las Empresas Sociales Griegas [ en ] Workers or Investors? Investigating the Reciprocity Aspects among Greek Social Enterprises Members," no. December, 2019.

[3] S. Jamal and M. A. Soomro, "Management Styles and Employee Performance: A Study of a Public Sector Company," South Asian J. Manag. Sci., vol. 5, no. 2, pp. 65-71, 2011.

[4] S. Tewari, R. Gujarathi, and K. Maduletty, "Leadership Styles and Productivity," Asian Soc. Sci., vol. 15, no. 4, p. 115, 2019, doi: 10.5539/ass.v15n4p115.

[5] A. Saleem, S. Aslam, H. B. Yin, and C. Rao, "Principal leadership styles and teacher job performance: Viewpoint of middle management," Sustain., vol. 12, no. 8, pp. 115, 2020, doi: 10.3390/SU12083390.

[6] J. Chukwusa, "Autocratic leadership style: Obstacle to success in academic libraries," Libr. Philos. Pract., vol. 2019, no. December 2018, 2019.

[7] S. Sasidaran, "Impact of Training on Employee Performance: A Case Study of Private Organization in Sri Lanka," IOSR $J$. Bus. Manag., vol. 4, no. 6, pp. 646-661, 2018.

[8] 2016 World Health Organization; WHO, "Open Mindsets: Participatory Leadership for Health," World Heal. Organ., p. 36, 2016, [Online]. Available: https://apps.who.int/iris/bitstream/handle/1066 5/251458/9789241511360eng.pdf?sequence $=1$.

[9] A. Puni, S. B. Ofei, and A. Okoe, "The Effect of Leadership Styles on Firm Performance in Ghana," Int. J. Mark. Stud., vol. 6, no. 1, pp. 177-185, 2014, doi: 10.5539/ijms.v6n1p177.

[10] World Economic Forum, Global Gender Gap Report 2020: Insight Report. 2019.

[11] P. Verkerk, "fiedler' s contingency model of leadership effectiveness: background and recent developments . Department of Philosophy and Social Sciences Eindhoven University of Technology," vol. 9002, no. 1990, 2020.

[12] V. Seyranian, "Contingency Theories of Leadership," Encycl. Gr. Process. Intergr. Relations, pp. 152-156, 2009.

[13] M. Villoria and J. Carlos, "Global Encyclopedia of Public Administration, Public Policy, and Governance," Glob. Encycl. Public Adm. Public Policy, Gov., pp. 1-7, 2020, doi: 10.1007/978-3-319-31816-5.

[14] W. Cai, S. Khapova, B. Bossink, E. Lysova, and J. Yuan, "Optimizing employee creativity in the digital era: Uncovering the interactional effects of abilities, motivations, and opportunities," Int. J. Environ. Res. Public Health, vol. 17, no. 3, 2020, doi: 10.3390/ijerph17031038.

[15] J. F. Chung and O. Climate, "the Impact of Leadership Styles on Organizational," no. April, 2020, doi: 10.5281/zenodo.3766106.

[16] N. Bhatti, G. M. Maitlo, N. Shaikh, M. A. Hashmi, and F. M. Shaikh, "The Impact of Autocratic and Democratic Leadership Style on Job Satisfaction," Int. Bus. Res., vol. 5, no. 2, 2012, doi: 10.5539/ibr.v5n2p192.

[17] E. H. Al Khajeh, "Leadership styles on organizational performance," J. Hum. Reseources Manag. Res., vol. 2018, pp. 1-10, 2018, doi: 10.5171/2018.687849.

[18] Y. Alhassan, O. Ibrahim, M. Abdul-Basit Fuseini, G. Issah, and I. Eliasu, "Assessing the Effects of Leadership Styles on Staff Productivity in Tamale," Int. J. Econ. Commer. Manag., vol. I2, no. 9, pp. 1-23, 2014.

[19] U. D. Abasilim, D. E. Gberevbie, and O. A. Osibanjo, "Leadership Styles and Employees' Commitment: Empirical Evidence From Nigeria," SAGE Open, vol. 9, no. 3, 2019, doi: $10.1177 / 2158244019866287$.

[20] I. Bourini, A. Jahmani, R. Mumtaz, and F. A. Al-Bourini, "Investigating the managerial practices' effect on Employee-Perceived Service Quality with the moderating role of supportive leadership behavior," Eur. Res. Manag. Bus. Econ., vol. 25, no. 1, pp. 8-14, 2019, doi: 10.1016/j.iedeen.2018.11.001.

[21] R. J. Taormina and J. H. Gao, "Maslow and the motivation hierarchy: Measuring satisfaction of the needs," Am. J. Psychol., vol. 126, no. 2, pp. 155-177, 2013, doi: 10.5406/amerjpsyc.126.2.0155.

[22] L. Seery, "Maslow' s Hierarchy of Needs 
Maslow ' s Hierarchy of Needs," Business, no. November 2017, pp. 3-5, 2018.

[23] A. Kontogeorgos, N. Giannakopoulos, and F. Chatzitheodoridis, "Exploring the Quality Management Systems on Cooperatives Performance before the Economic Crisis," vol. 19, no. 164, p. 2018, 2018.

[24] Stavros Kalogiannidis, "Business Trust and Communication as Predictors of Business Growth," WSEAS Transactions on Business and Economics, vol. 18, pp. 1512-1522, 2021

[25] Francesca Pampurini, Anna Grazia Quaranta, "Critical Factors Affecting Bank Management Policies", WSEAS Transactions on Business and Economics, Volume 17, 2020, pp. 735740 .

Creative Commons Attribution License $\mathbf{4 . 0}$ (Attribution 4.0 International, CC BY 4.0)

This article is published under the terms of the Creative Commons Attribution License 4.0

https://creativecommons.org/licenses/by/4.0/deed.en US 